Marquette University

e-Publications@Marquette

$12-1-1993$

\title{
A Theological Context of Work from the Catholic Social Encyclical Tradition
}

Michael John Naughton

Marquette University

Gene R. Laczniak

Marquette University, eugene.laczniak@marquette.edu

Accepted version. Journal of Business Ethics, Vol. 12, No. 12 (December 1993): 981-994. DOI. (C) 1993 Springer International Publishing AG. Part of Springer Nature. Used with permission. 
NOT THE PUBLISHED VERSION; this is the author's final, peer-reviewed manuscript. The published version may be accessed by following the link in the citation at the bottom of the page.

\title{
A Theological Context of Work from The Catholic Social Encyclical Tradition
}

\author{
Michael Naughton \\ Managment Department, Theology Department, \\ University of St. Thomas \\ St. Thomas, $M N$ \\ Gene R. Laczniak \\ Department of Marketing, Marquette University \\ Milwaukee, WI
}

\begin{abstract}
The 100 years of writing known as the Catholic social tradition (CST) provides principles and virtues that can help direct the essential activities of all workers toward the common good as well as the affirmation of their own dignity. Using this tradition as a guide, the nature of work is explored along with the principles and virtues which vitalize the deepest dimension of work - how it affects the dignity of the human person. Insofar as work has a self-determining effect on the person it is subjective. Insofar as work has an effect on an external object it is objective. From these subjective and objective dynamics 4 concrete dimensions of work are derived: 1 . formation - how work affects the person, 2. remuneration from work, 3 . the process of the workplace, and 4 . the product which is produced. Participation,
\end{abstract}


like worker ownership and production of socially responsible products, will in the long run probably be the best financial strategy, but the foundation of such action should be moral rather than financial.

In May of 1991, Pope John Paul II issued his third social encyclical entitled Centesimus Annus ("On the Hundredth Anniversary of Rerum Novarum"). As the title indicates, the encyclical was written to commemorate Leo XIII's encyclical Rerum Novanrum ("On the Condition of Labor"). John Paul provides a rereading of Rerum Novanrum in light of today's new things (Chapter 1-2). He also discusses the revolutionary events of Eastern Europe (Chapter 3), the plight of the developing world (Chapter 3), the universal destination of material goods (Chapter 4), the role of the state (Chapter 5), and the Church's role concerning the social questions of today (Chapter 6). Several other papal encyclicals, council documents, and pastoral letters have been written in this one hundred year tradition, offering moral commentary concerning economic issues.

We are particularly interested in what John Paul has to say concerning work. He describes the historical development between the relationship of work and land (property and capital). In the past, land was the prime factor toward the accumulation of wealth; whereas work served as a secondary and supporting factor. However, today "the role of human work is becoming increasingly important as the productive factor both of non-material and material wealth" (Centesimus Annus, 31 ). With the increasing transition from an industrial to an information based economy, work, according to John Paul, has become the prime factor in the creation and distribution of wealth. This is why today an understanding of work is imperative in examining a just and humane world.

This article analyzes the papal social encyclicals and the ethics they imply for an understanding of work. We argue that the Catholic social tradition (also called Catholic social thought) or CST provides principles and virtues that can help direct the essential activities of all workers toward the common good as well as the affirmation of their own dignity. By understanding the very nature of work as a moral activity, this tradition provides a theology of work that functions as an ethical framework to evaluate work related issues. This article explores the presupposition that work, as a human activity, is an inherently 
value-laden activity. CST does not provide a blueprint of how the organization should be setup. It does, however, provide an orientation that perceives work as an act of virtue as well as a means to a financial end. As such, the principles and virtues of CST furnish a context for the U.S. workplace in which people can understand their work. Let us begin with an exploration of the nature of work as well as some important conceptual distinctions which are consistent with CST.

\section{Work: Defining It}

As a formative activity, work affects both the person and society, that is, both the subject and the object. Insofar as work has a self-determining effect on the person it is subjective. Insofar as work has an effect on an external object (i.e., the product or service) it is objective. These two outcomes which flow from the product consists of the relationship between the activity of work occur simultaneously.(1) From these subjective and objective dynamics we can derive four concrete dimensions of work: (a) formation--how work affects the person; (b) remuneration from work; (c) the process of the workplace; and (d) the product which is produced.

The formation of the human person is the central product moral dimension of work. It focuses on the changes work brings about in an individual's personality, character, and potential as a human subject. In order to understand work, it is imperative to understand the person who is performing the work and how he/she is affected. In studying the formative dimension, one attempts to understand how work affects the economic, socio-psychological, ethical, and spiritual characteristics of the complex person. The formative dimension usually pervades the other three dimensions of work and it is at the heart of the ethical questions about work which are raised in this article.

Remuneration is a second distinctive and essential characteristic of work. ${ }^{2}$ For most people, work is not an option but a necessity. It is the primary means to support themselves and their families. This need to work both affects peoples' psychological make-up and greatly determines their quality of life. The study of remuneration includes looking at such things as wages, incentive programs, and workers' ownership of the firm. It also includes the effect remuneration has on the worker as well as the general welfare of society.

Journal of Business Ethics, Vol 12, No. 12 (December 1993): pg. 981-994. DOI. This article is @ Springer and permission has been granted for this version to appear in e-Publications@Marquette. Springer does not grant permission for this article to be further copied/distributed or hosted elsewhere without the express permission from Springer. 
Since work has a formative effect on the worker, the process of producing goods and services is also significant. This third dimension-the work process--consists of the manner in which work is performed. What is of particular importance in the process is the way the workplace is actually organized. The workplace is not only where products are made, it is also where people are changed. The process used good by the firm is extremely important, since the person who performs in this process is an integral part of the system. In the past, many modern production structures have tended to foster worker passivity and apathy. This is particularly true among assembly line blue collar positions, bureaucratic middle management jobs, and minimum wage service sector positions.

The product or service produced has both an internal and external aspect. The "internal" aspect of the product consists of the relationship between the worker who has created the product and the product itself. If workers take very little pride in the quality and craftsmanship represented by the product or if they perceive that what they produce has minimal social virtue, little hope exists that the work will be considered dignified. The "external" aspect of the product consists of the effects of the product, that is, the externalities of social costs/benefits of the product on customers, culture and the environment.

Work, then, is an activity that causes changes in the subject and the object. Whether these changes are positive or negative will depend to a great extent on how the work is organized, the workers themselves, and the object that is produced. Because work has a personal effect on the subject and a social effect on society, it is a peculiarly human activity. As a human activity, work is inherently value-laden, because any discussion concerning the human person and society, whether the person is viewed as an economic agent, a psychological being, or a moral creature, is ultimately a discussion of values. Any comprehensive vision of work, then, presupposes a vision of the person and consequently an ethic for the workplace. CST provides such a vision and a set of ethics. 


\section{Different Views On The Meaning Of Work}

If work has such a dramatic effect on workers and society, then what is its ultimate purpose? How should work be envisioned? Robert Bellah and his contributors address this question in their book Habits of the Heart (1985) under three categories: work as job, work as career, and work as calling. First, work can be understood as a job-the means by which people make money so as to consume goods. "It supports a self [who is] defined by economic success, security, and all that money can buy." ${ }^{3} \mathrm{~A}$ job corresponds to work extrinsically understood. It is defined by its extrinsic benefits, such as wages, perks, working conditions, and so forth. From this become perspective, work is valued for its material gains. "Work as job" reflects in part the principles honed in the tradition of Frederick Taylor's system of scientific management. According to this view, the primary purpose of work is to increase efficiency and productivity so as to increase profits and wages.

Next, work understood as a career traces the progress of peoples' work through their achievements and advances in a particular occupation. The worker becomes defined by social standing and prestige as well as "by a sense of expanding power and competency that renders work itself a source of self-esteem". ${ }^{4}$ This career approach entails both the intrinsic and extrinsic understanding of work. "Work as career" reflects the psychologic concerns of the Human Relations School. Its primary focus is to increase workers' satisfaction by increasing their self-esteem, which in the end also increases productivity.

Third, work understood as a calling (or vocation) connects work's purpose with the proximate and ultimate end of a person's life. Work is more than social just a source of material and psychic rewards. As Bellah et al. explain, "A calling links a person to a larger community, a whole in which the calling of each is a contribution to the good of all....The calling is a crucial link between the individual and the public world." ${ }^{5}$ Work is not only a psychological or financial affair, but its activity extends beyond the person and the object that is created. Work must be directed toward a larger end--the common good. It ought to have a humanizing effect that binds workers more

Journal of Business Ethics, Vol 12, No. 12 (December 1993): pg. 981-994. DOI. This article is @ Springer and permission has been granted for this version to appear in e-Publications@Marquette. Springer does not grant permission for this article to be further copied/distributed or hosted elsewhere without the express permission from Springer. 
closely together and contributes to society's general welfare. ${ }^{6}$ As discussed further, this is the perspective of work inherent in CST.

Clearly, Bellah et al. side with the third dimension of work--work understood as a calling. Their point is not to deny the value of work defined as job and career. The fact is that work is a job. It is a means to a financial end. If work as employment does not generate income, no matter how noble or psychologically satisfying, in the end it is problematic. And work should be psychologically satisfying. Climbing the ladder of success, learning a skill or increasing one's self-esteem are satisfying activities. But if these two understandings fail to be connected to a larger good that extends individuals and organizations beyond their own private concerns, work eventually becomes an exercise in self-interest--that is, the satisfaction of the pocketbook or the psyche. Bellah et al. point out in their new book The Good Society (1991) that if work is reduced to technical competence or self-esteem the possibility of "any larger moral meaning, any contribution to the common good", becomes remote. ${ }^{7}$ Work then turns out to be a matter of acquiring "a high level of competence, of expertise, of 'professionalism', not the moral wisdom that should be at the basis of any good institution".8

Bellah and his contributors state that if people in society are ever to become more virtuous "a reappropriation of the idea of vocation, [and] a return in a new way to the idea of work as a contribution to the good of all" will be indispensable. ${ }^{9}$ The CST can contribute to this "reappropriation". This tradition provides insights that can address the deficiencies of work understood as a job or career. The comments about CST that follow are not offered because of their sectarian roots but rather because they offer a rich amplification of the concept of "work as a vocation". The Catholic church's social teachings are broad enough not to undermine the specific insights offered by organizational schools of thought grounded in Taylorism or the Human Relations approach; yet, they are specific enough to address some of their deficiencies. CST is not a substitute for these organizational schools, but rather a supplement that provides a moral and religious vision encompassing the purpose of work.

Sunk in a historical tradition going back over 100 years, CST illustrates an understanding of work formed within a moral order; 
without this, work fails to reach its ordered end. When Leo XIII wrote Rerum Novarum 100 years ago, it was a response to the Industrial Revolution which he believed was reducing the activity of work to a mere technique to further the profits of owners. Every pope since Leo has harkened this warning in some form. [Below in Exhibit I is a list of the major Catholic documents on the topic of work, and a brief description of their historical contexts.] We now turn our attention to the specifics of CST and how it relates to "work as vocation" along with the insights it provides concerning the formative aspects of work.

\section{Exhibit I}

\section{Catholic social tradition--the major documents on work}

I. Leo XIII (1878-1903) Rerum Novarum (The Condition of Labor) 1891--The encyclical came about as a reaction to the inhumane condition of the worker and the growing option of socialism. Leo's solution centered on a wider distribution of private property, just wages, limited government involvement, and renewal of free associations.

II. Pius XI (1922-1939) Quadragesimo Anno (On Reconstructing the Social Order) 1931--As Leo responded to the abuses of the industrial revolution, Pius responded to its apparent demise in the Great Depression. Pius XI's solution was associations both on the macro level where labor, management and government would plan out the economy, and on the micro level where labor and management would enter into partnership contracts.

III. Pius XII (1939-1958) "Allocutions"--Although Pius XII never wrote an encyclical on the social question, he wrote numerous addresses on such varied subjects as unions, wages, codetermination, work as vocation and profession, unemployment, and technology in a historical context of post World War II reconstruction. One of Pius XII's gravest concerns for the workplace was the depersonalization of the worker as a result of technological growth.

IV. John XXIII (1959-1963) Mater et Magistra (Mother and Teacher) 1961--John XXIII by articulating principles and virtues in the area of responded to the increasing complex and interdependent 
nature of social relations and social institutions. In the 1950 s and 60s, this was brought about by progress in technology, the increasing role of government, and the furthering education of the worker. He responded to these historical circumstances by expanding the concept of human dignity into a wage principle of "justice and equity" and a production process principle of "participation."

\section{John Paul II (1978-Present) Laborem Exercens (On Human} Work) 1981--This document is the most systematic exposition on the nature of work by any pope. John Paul II contends that to understand work one must have a sound anthropology which originates from Genesis, namely, the person is the Image of God. who is called to subdue, dominate and till the earth. This doctrine from Genesis provides the meaning of work, basically that in work people remain true agents and that both the means of production and the fruit of labor are at the service of those who work (i.e., the person has a transcendent value). Because people are made in the image of God, every aspect of work is subject to their dignity.

Centesimus Annus (One Hundred Years) 1991--Whereas Laborem Exercens is systematic, Centesimus Annus is historical. In the area of work, John Paul II explains the increasing importance of information regarding skills and technology, and entrepreneurial virtues in the production process. His evaluation of the market economy is positive overall; however, he is concerned over the increasing phenomenon of consumerism, which he believes is a partial cause of the various social problems, especially environmental degradation.

VI. U.S. Catholic Bishops Statements Program of Social Reconstruction 1919 and Economic Justice for All 1986--The bishops of the U.S. have attempted to apply the papal and council teaching to the specific situation in the U.S. They have also attempted to develop the tradition in a U.S. context. Issues such as unemployment, poverty, plant closings, worker ownership and participation, etc., pervade both of the documents. 


\section{Catholic Social Principles And Virtues Of Work}

For the past one hundred years, both the popes and the U.S. Catholic bishops have emphasized the moral and religious character of work. They have done this by articulating principles and virtues in the area of work that contribute to the edification of society and the dignity of the person. The popes and bishops do not offer a specific organizational blueprint for the workplace, but the principals and virtues they expound provide a direction for each dimension of the organization. For instance, the principle of common use and the virtue of justice have been applied to the dimension of remuneration. The principal of participation and virtue of industriousness or diligence have been applied to the dimension of the production process. The principle of the common good and the virtue of magnificence have been applied to the dimension of the product produced. And, in the area of formation, the principle of human dignity has been a resounding theme which provides a foundation for all other principles and virtues, with the virtue of solidarity highlighting the social nature of the human person. This is not to say that these particular virtues and principles are the only ones associated with CST. Various principles and virtues can be applied in a variety of different circumstances, but some nonetheless make more sense in certain areas than in others. For purposes of illustration, the paragraphs below will flesh out the meaning of only one principle or virtue for each dimension of work. [Exhibit II below provides a brief definition of each principle and virtue mentioned above.] The discussion which follows then becomes the specification of the essentials of CST in workplace ethics.

\section{Exhibit II}

\section{Catholic Social Principles And Virtues}

I. Formation A. The Principle Human Dignity. Everything in the economic and organizational realm must be judged in light of whether it protects or undermines human dignity. This dignity is grounded in the transcendent dimension: that the person is created in the image of God. Each individual's life is intrinsically valuable and sacred, and hence ought never be treated as a means. Economic and 
organizational life has a powerful formative effect on people. How that type of life is structured must contribute to the edification of the human personality.

B. The Virtue of Solidarity. John Paul II explains that all economic activities, including work, have an interdependent nature. This interdependence should be formed by the virtue of solidarity which is "a firm and preserving determination to commit oneself to the common good" (Sollicitudo Rei Socialis, 38). For John Paul II, the fact that people are interdependent in their work demands solidarity. People do nor work only for themselves. They also work for their family, their community, their nation, and for all of humanity.

II. Remuneration A. The Principle of Common Use/Private Property. Within the Catholic social tradition, common use and private property complement rather than contradict each other. The best way to guarantee private property is to work toward common use, and the best way to guarantee common use is to work toward private property. When conflict does occur, common use, that is, the universal destination of creation, takes priority over private property. Expropriation is legitimate since all property has a "social mortgage." Hence, the right to private ownership is not absolute, but always subservient to common use.

B. The Virtue of Justice. Justice is that virtue which defines that which is due to another. In the area of work, justice treats mainly the issue of remuneration. Because work is necessary for the preservation of one's life, any wage theory must call for a wage commensurate with the necessary character of human work. The proper object of justice is not the strict economic exchange of what is "due," but must include the common good based on the dignity of the person. Hence, one's due in reference to wages must be a living wage.

III. The production process $A$. The Principle of Subsidiarity/Participation. Subsidiarity is a principle that guides all social life and is not merely meant to limit state authority. If one applies this principle to the workplace, participation becomes a demand of justice, not an option of charity, due to the fact that it limits the authority of the employer. Workers, according to the principle of subsidiarity, should perform their work in an autonomous

Journal of Business Ethics, Vol 12, No. 12 (December 1993): pg. 981-994. DOI. This article is @ Springer and permission has been granted for this version to appear in e-Publications@Marquette. Springer does not grant permission for this article to be further copied/distributed or hosted elsewhere without the express permission from Springer. 
environment unless they either cannot or will not perform their work competently. The true nature of all social activity is to help individuals become active participants in every social body. Social and economic control should be kept at the lowest possible level, giving primacy to individual initiative.

B. The Virtue of Diligence and Industriousness. Diligence and industriousness are important virtues to wealth creation. In Centesimus Annus (CA), John Paul associates these virtues with the activity of entrepreneurship. As the "principal resource" in the organization, workers should be given the opportunity and freedom to actuate their ingenuity, creativity and intelligence throughout the production process. For John Paul, these virtues are important in disciplined work which "makes possible the creation of ever more extensive 'working communities'" (CA, 32).

IV. Product related issues A. The Principle of the Common Good. The person is social by nature and hence must be seen in relationship to the community. Society is not a collection of individuals who make a "social contract," but rather an organic unity of which the family is the most basic cell, but which also includes the workplace, the state, and other organizations. The Catholic understanding of the common good is not "the greatest good for the greatest number." Rather, as John XXIII stated in Mater et Magistra (MM), the common good is "the sum total of those conditions of social living, whereby men are enabled more fully and more readily to achieve their own perfection" (MM, 65).

B. The Virtue of Munificence. The primary object of the virtue of munificence is the actual production of some product or service which contributes to the social good (QA, 132). The virtue of munificence is illustrated in the creation of good and useful products and services promoting the common good. Investment ventures, as well as the organization as a whole, must have a direction that is in harmony with the common good. Products should not be produced solely for the purpose of fulfilling the wants of the market, nor even for the creation of jobs. Neither are investments determined exclusively by economic categories under the assumption that such decisions have an amoral character. Fundamentally, investments and products have a moral and even a spiritual character that can never be reduced to economics.

Journal of Business Ethics, Vol 12, No. 12 (December 1993): pg. 981-994. DOI. This article is @ Springer and permission has been granted for this version to appear in e-Publications@Marquette. Springer does not grant permission for this article to be further copied/distributed or hosted elsewhere without the express permission from Springer. 


\section{The Principle Of Common Use And Remuneration}

Following the CST, John Paul II states in Laborem Exercens (LE) that the first principle of the socio-economic order is "the universal destination of goods and the right to common use of them" (LE, 14.4; see 30-31). This implies that every person is meant to share in the goods of creation. Prior understanding of the CST called for common use of creation, especially in the form of wages so as to buy property for one's family. It did not connect the principle specifically with ownership of the means of production. For John Paul II, however, worker co-ownership of the means of production is a form of ownership which successfully appropriates the principle of common use.

One of the most serious problems preventing a right to common use in CST is the suspicion between the representatives of capital and labor. A fundamental reason for this antipathy is the separation of the means of production from workers. Such opposition in the workplace is unfortunate. LE states that by isolating the means of production "as a separate property in order to set it up in the form of 'capital' in opposition to 'labour'" one violates the purpose of use and possession for which these means of production were originally destined (LE, 14.2).

In the CST, property is not a right in and of itself. It is a means to utilize the principle of common use, which furthers human dignity. In $L E$, it states that justice is achieved when capital serves labor. In order for capital to serve labor, it ought to be at labor's disposal, particularly through ownership. Ownership of capital, namely the means of production, "is acquired first of all through work in order that it may serve work" (Ibid.). According to this view, the only criterion for legitimate entitlement to ownership of the means of production is capital's service to labor. The means of production should serve the principle of common use. By connecting the principle of common use to some form of worker or joint ownership, John Paul II re-envisions ownership. He perceives ownership not as a form of worker selfinterest (as opposed to managerial self-interest) but as a quest to fulfill the principle of common use. He never absolutizes worker ownership, since it is only one form of property among many. But it is 
a means to the larger goal of common use. And, worker ownership is perceived in LE as one of the best means to achieve one of the ultimate ends of common use, namely, a just distribution of goods.

Worker ownership serves other ends as well. It can fulfill the personal component of the principle of common use. In LE, this personal component is referred to as the "personalist argument". The document points out that the "Church's teaching has always expressed the strong and deep conviction that man's work concerns not only the economy but also, and especially, personal values" (LE, 15.1). The rule of ownership ought to be at the service of "personalistic values." Workers are not concerned only with what they receive from their labor (extrinsic benefits). They also want to know what they are working for themselves (intrinsic benefits). It is difficult for workers to have a personal connection to what is not their own. LE states that worker ownership contributes to the personal development of the individual worker, that is, to the formative dimension of work. Another aspect of this personalistic component of worker ownership is that it creates stronger social relationships between employees and employers. Worker ownership is advocated by LE (as well as by the CST in general) not only because it distributes the wealth, but because it serves well as a means to personalization by affecting positively the formative dimension of the person and creating stronger social relationships between worker and employer.

Thus, the first operational proposition of the workplace which flows from CST is the following: (i) whenever possible, mechanisms should exist which allow workers to attain partial ownership of their organizational enterprise.

\section{The Principle Of Participation And The Production Process}

The principle of participation applied to the production process becomes most clear in John XXIII's encyclical Mater et Magistra (MM), and serves as a basis for what is said in the writings of John Paul II as well as the U.S. Catholic Bishops. Worker participation is justified on two levels (MM, 93): 1) natural law: a participatory nature exists in each person which needs to be exercised in order to fulfill the human 
personality; 2) changing social conditions: social and economic changes call for worker participation both on a moral level and on an efficiency level. Each of these aspects is described in further detail below.

Natural Law. MM legitimizes worker participation by rooting it in human nature. It places great emphasis on workers as partners in the process of production, who partly perfect and fulfill their humanity through that process. If the dignity of the human person is held seriously, work must allow the opportunity for workers to develop their talents and potentialities in the production process. Workers should participate in the important functions of the company. This would enable workers to actualize their talents since "every person has by his very nature, a need to express himself in his work and thereby to perfect his own being" (MM, 82). Worker participation springs from human nature and is therefore a matter of justice and rights. Hence, the concerns of justice treat not only remuneration and the distribution of wealth, but also the conditions in which people are engaged in the process of production. This logic leads MM to state that worker participation is an essential means to the unfolding and development of the individual's personality, and consequently must be considered a matter of justice and rights.

Hence, the reason for MM's advocacy of participation is primarily based on the development of the human personality and consequently on the respect of human dignity. John XXIII takes seriously the idea hat if workers are not able to act for themselves, that is, to have some sense of personal initiative, they would not be able to develop their personalities fully. He places great emphasis on all areas of life, particularly in the economic order (MM, 51). When people initiate things they begin to exercise their freedom and develop their personalities in a more wholesome and complete way than if they are simply told and directed everything by higher authorities. This is what the CST means by the principle of subsidiarity.

Personal initiative, while important and necessary for the organization, must never lapse into anarchy. MM states that in order for the dignity of workers to be developed, the firm must "maintain a necessary and efficient unity of direction" (MM, 92). Personal initiative and responsibility in the firm must fall within the bounds of orderly 
managerial oversight; otherwise, it wanders into oblivion. The economic nature of the enterprise cannot afford unlimited creativity and initiative. As to everything there are limits. Yet, MM goes on to assert that the "unity of direction" of the firm also has its limits. The firm must not treat those employees who spend their days in service with the firm as though they were mere cogs in the machinery, denying them any opportunity of expressing their wishes or bringing their experience to bear on the work in hand, and keeping them entirely passive in regard to decisions that regulate their activity (Ibid).

Management has the right to direction and determination, but it does not have the right to keep the worker passive and inactive.

Changing Social Conditions. Although John XXIII places primary importance on participation as a fulfillment of human nature and personal dignity, he also argues that worker participation is efficacious in light of the changes and progress in economic, social, and political areas (MM, 93). As the world becomes more complicated and interdependent, all workers will be expected to function in an environment demanding more knowledge. For example, the modernization of production and service systems demands higher qualifications in technical matters as well as a higher degree of communication skills from workers. If the more technical and interdependent production systems are to run smoothly and efficiently, they must be coupled with a more educated and communicative workforce (MM, 94).

MM is extremely optimistic about the modernization of the workforce (MM, 47-48). As the technical and scientific advancements occur in the workplace, the organization will become more efficient, hence improving the distribution of wealth and increasing the professional qualifications and the technical skill of its workers. Due to this scientific and technological progress, workers will have to spend more time to complete their vocational and professional training. MM states that this training will lead to further opportunities for "cultural, moral and religious education" (MM, 94). This educational advancement can remove the stigma among workers as managerially unqualified, which is often a major reason why many argue against worker participation. Further, as workers become more educated, John 
XXIII asserts they will want "to assume greater responsibility in their own sphere of employment"(MM, 96). He contends that as the level of education increases, more people will want to become involved in the decisions of their work, largely because they have more to offer if they have a higher level of education. ${ }^{10}$

MM maintains that as an expression of the person, the dignity of work grows more out of workers' professional skills than out of the capital goods they attain from work. Without lessening the importance of capital and private property, the document views work as a higher rank than capital and property. Labor is intrinsic to workers. It comes from their personhood. MM maintains that as the immediate expression of the worker, labor "must always be rated higher than the possession of external goods which of their very nature are merely instrumental"(MM, 108 and 242). As labor is developed with further skills and expertise, it always stays with the person and should have various positive effects. Monotonous and back-breaking work should decrease and technical, intellectual, and artistic skills which manifest the faculties of the whole human person should increase. This not only gives more dignity to workers by professionalizing their work (i.e., responsibility, skill, moral standards, etc.), it also provides better economic security for the worker. This professionalization can take place by furthering the education of the worker and by restructuring the workplace to incorporate the "whole" worker.

The above leaves us with two further operational propositions for the workplace: (ii) management and employees should strive to create systems that maximize employee participation, and (iii) management has the obligation to provide training and educational opportunities for everyone.

\section{Products Produced And The Virtue Of Munificence}

For Pius XI in Quadragesimo Anno (QA), the fundamental principle in understanding the purpose of products and services, is related to the social function of property and is rooted in an essential aspect of the natural law. This view is based on the position that God has provided the resources to serve the needs of all people. He explains that the natural order demands that nature's resources ought to be organized primarily in light of human needs. According to QA, "It 
follows from the twofold character of ownership, which we have termed individual and social, that men must take into account in this matter not only their own advantage, but also the common good" (QA, 49). Those who own and control natural resources should direct and develop such resources to maximize the good of society, which is the ultimate purpose of creation intended by God. In other words, producers of goods and services have a social obligation to direct their productive capacities to the common good.

QA further explains that the social function of property has particular significance for the wealthy--those in control of capital. After discussing the social function of wealth, it encourages those who invest to direct their resources toward products and services that contribute to the overall good of society (social investment). When investors act with this sort of intention behind their investments, they are practicing the virtue of munificence. In his commentary on QA, Oswald von Nell-Breuning calls munificence "a genuinely capitalistic virtue", that is, "a a virtue for the entrepreneur". ${ }^{11} \mathrm{He}$ explains that only the entrepreneur who "gives first thought to service and second thought to gain" practices the virtue of munificence. Nell-Breuning further explains that munificence is manifested in that person who in his enterprise and in his means of production employs his working men for the creation of goods of true worth; who does not wrong them by demanding that they take part in the creation of futilities, or even harmful and evil things; who offers to the consumer nothing but useful goods and services rather than, taking advantage of the latter's inexperience or weakness, betrays him into spending his money for things he does not need, or that are not only useless but even injurious to him. ${ }^{12}$

Investment efforts as well as determining what products to produce must have a direction that is in harmony with the common good. Products should not be produced only for the purpose of fulfilling the whims of the market, or even the creation of jobs. Investments should not be determined only by economic factors. Fundamentally, investments and products have an ethical and even a spiritual character that can never be reduced purely to economics. Entrepreneurs, managers, and workers are all partially responsible for what they produce. Some are in a special position concerning the economy, particularly entrepreneurs and managers who have more 
power than others in the determination of goods and services, just as politicians have more power than others in the determination of social policy.

In $\mathrm{QA}$, the virtue of munificence is a means to actually restore the common good within society. Without useful goods and services, a society will flounder in triviality and selfishness. The document maintains that useful products ought to supply needs, provide an honest livelihood, and echoing Rerum Novarum (RN), "uplift men to that higher level of prosperity and culture which, provided it be used with prudence, is no hindrance but is of singular help to virtue" (QA, 75; RN, 50-51). For the CST, the purpose of producing goods and services ultimately rests on the development of the human person. This in turn is essential to attain the common good. The virtue of munificence directs the activity of investment as well as the production of products and services toward this end, while at the same time making the person who performs the act more virtuous. ${ }^{13}$

The above provides us with a fourth and fifth operational proposition of the workplace: (iv) management and employees have the moral obligation to consider the impact their product or service has on the commonweal, and (v) investors must use social as well as financial criteria in determining investment decisions.

\section{Workplace Programs And Practices}

In the CST, work has a formative dimension that implies a moral responsibility to develop those programs which increase worker creativity, community, and autonomy, and to decrease whatever structures might stifle worker initiative, ingenuity, and moral development. The CST maintains that such goals are an inalienable aspect of organizing people. Organizational policy that respects the formative dimension of the worker ought to try to create an environment that allows participation of workers in the ownership and production process as well as the creation of products that contribute to the public good. The point of this section is not to glorify the programs or practices discussed below. These efforts are not without their problems, as the current organizational literature has shown. ${ }^{14}$ Nor is the point to demonstrate that the programs are a mandatory consequence of the CST; depending on the situation, they may not be. 
NOT THE PUBLISHED VERSION; this is the author's final, peer-reviewed manuscript. The published version may be accessed by following the link in the citation at the bottom of the page.

Rather, the goal is to show that principles and virtues of the CST provide a distinct direction that is helpful in evaluating workplace issues.

Worker Ownership. ESOPs (Employee Stock Ownership Plans) serve as one of the most tangible and readily available programs to distribute and personalize ownership of the means of production. However, ESOPs have suffered certain structural problems which prevent true personal development. For example, $85 \%$ of private ESOPs prohibit employees from voting with other stockholders unless the issue voted on concerns selling, liquidating, moving, or merging the company--a stockholder right which cannot be legally restricted. Furthermore, the administrators of the trust established by the ESOP are typically appointed not by the workers but management. As a result, trustee decisions tend to serve the interests of management. Thus, ownership itself does not always guarantee fuller participation by the worker. ESOPs were not designed as a mechanism for workers to exert managerial control. In large organizations, it is unrealistic to expect that (collectively) workers holding shares are likely to be on the same plane as other large minority shareholders. ESOPs mostly allow for a sharing of the profits. As a vehicle for achieving managerial control, ESOPs by themselves are not realistic. However, in conjunction with other factors, they are a mechanism toward meaningful employee participation.

Studies have found that the key to successful ESOPs (both in personal and financial terms) is whether the company supplements partial ownership with true participation for the worker. One of the most interesting findings from Rosen and Quarrey (1987) is the correlation between participative management and ESOPs. ${ }^{15}$ They found that companies with both participation plans (Quality Circles, Work-Teams, etc.) and ESOPs grew 3-4 times faster than chose companies with just ESOPs. A prime example of an ESOP company with participation programs is Weirton Steel, whose 7,000 workers bought the firm in 1984. The internal participating in the decision making once reserved operations of the company changed from a top/down decision making policy to a horizontal decision making policy that set up intensive three-day training programs to teach employees to run employee involvement teams on their own...installed television monitors throughout the plant to keep employees informed of has been granted for this version to appear in e-Publications@Marquette. Springer does not grant permission for this article to be further copied/distributed or hosted elsewhere without the express permission from Springer. 
NOT THE PUBLISHED VERSION; this is the author's final, peer-reviewed manuscript. The published version may be accessed by following the link in the citation at the bottom of the page.

developments, and...[sharing] detailed financial and production data, good and bad with employee-owners. ${ }^{16}$

Weirton has turned a profit every quarter since the ESOP was instituted. They have added 1500 employees to handle the additional growth, and they have out-performed most other steel companies since that time. ${ }^{17}$

For John Paul II, worker ownership is a key ingredient to efficiency properly achieved. In Centesimus Annus, he explains that the efficiency of a particular organization is not only a technical issue, but also a consequence "of the human rights of private initiative, to ownership of property and to freedom in the economic sector" (CA, 24). Worker ownership, along with participation, provides a moral base that can both respect the nature and dignity of the worker as well as tap the potentialities of the worker's talent and increase profits.

Worker Participation. The present status of worker participation in the U.S. has improved dramatically in the last ten years, but overall it is still rather sporadic. One study projected that approximately $60 \%-$ $70 \%$ of all workers participate little if at all in the decision making of their workplaces. ${ }^{18}$ Even though many companies may have some form of worker participation, often only a few employees are involved. The U.S. General Accounting Office reported that $70 \%$ of 476 large companies they surveyed had some form of participative management; however, $70 \%$ of those companies studied also had less than half of the employees involved. ${ }^{19}$ One program that attempts to foster worker participation on a more pervasive plane is the work-team approach.

Work-teams fundamentally redesign work by creating permanent group structures in the organization. Work-teams place the traditional managerial functions of planning and organizing work in the control of employees. Employees become an integral part of the dayto-day affairs of the company by participating in the decision making once reserved solely for managers. Many organizational theorists maintain that work-teams represent a dominant future trend in work design since it meets two fundamental requirements of the workplace: sociality and productivity. As Lee Hardy points out, this "sociotechnical approach [of work-teams] is the wave of the future because

Journal of Business Ethics, Vol 12, No. 12 (December 1993): pg. 981-994. DOI. This article is @ Springer and permission has been granted for this version to appear in e-Publications@Marquette. Springer does not grant permission for this article to be further copied/distributed or hosted elsewhere without the express permission from Springer. 
it best comports with new market demands for flexibility, rapid response, creative problem-solving and direct client [and employee] relationships." 20 With work-teams, managers function more like a support-staff than like authority figures. In their book Workplace 2000, Joseph Boyett and Henry Conn argue that employees in work-teams are required to "seek out information the group requires, to make decisions without the supervisor's input, and to initiate action to change policies, procedures, methods of performing day-to-day activities". ${ }^{21}$

An important characteristic of the work-team approach is its decentralization. The CST has encouraged decentralization based on the principles of subsidiarity and participation. For this tradition, subsidiarity and participation are important organizational principles in the ordering of the production process. The high value of personal initiative and the belief that people can determine their destiny are the foundation of these principles. If workers can make the decisions and contribute to the welfare of the organization, they should. They have a right to. Workers, according to the principles of subsidiarity and participation, should perform their work in an autonomous environment unless they cannot or will not perform competently. They should be given the possibility to be responsible and accountable for what they do. ${ }^{22}$ In Centesimus Annus (CA), John Paul II explains that this decentralization in the firm will weaken "consolidated power structures" which then will not only contribute to the integral development of the worker but also enhance the long-term efficiency of the firm $(C A, 43)$.

Work-teams have been able to concretize Mater et Magistra's hope that workers would become more skilled and educated as well as the emerging concern in CA that "the possession of know-how, technology and skill" provide participation both in the work process as well as to appropriate remuneration (CA, 31-32). CA further discusses the marginalization of the worker from the knowledge of information. Today, many workers are unable to participate in the production process because they lack skill and information. This marginalization occurs due to the fact XIII that people "do not have the means which would enable them to take their place in an effective and humanly dignified way within a productive system in which work is truly central" $(C A, 33)$. The ownership of information concerning the "possession of 
merely know-how, technology and skill" has become more important than the ownership of land--at least in developed countries like the United States. Hence, the kind of worker knowledge one has to offer increases in importance. Those who are unskilled merely can no longer afford to remain so. And those who are skilled need continually to update their skills.

Producing Socially Responsible Products. The product dimension of work does not imply any specific formal program like work-teams or ESOPs (except quality programs), but rather the general practice of virtue. The effects of products in society range from industrial waste that is polluting the earth and advertising campaigns that seemingly manipulate the most vulnerable classes of society (e.g., malt liquor), to life saving technologies and inexpensive staple products. This range of outcomes can even be produced in one company (e.g., Philip Morris Inc. : tobacco--Philip Morris, and food products--Kraft). Unfortunately, within an organization, deciding what kind of product should be produced is often reduced to whether it is legal to produce and market it, and whether it will do well in the marketplace. Producers who promote products of dubious value and quality, largely abdicate their responsibilities by arguing that if consumers do not want the product they do not have to buy it. They contend that the moral responsibility for what is produced rests on the consumer not the producer. They postulate: "first the consumer demands, then the organization supplies". Phil Land explains that since the consumer ultimately decides the enterpriser cannot be blamed if the goods produced are trivial in value, noxious, dangerous to health and fail to meet basic needs. The business community thus escapes responsibility for socially objectionable production. If an irrational public demands stupid and dangerous goods the business world can only in duty comply. ${ }^{23}$

Arguments similar to those that justified a sub-living wage in the late nineteenth century justify the development of ecologically and socially damaging products today. In the late nineteenth century, Leo XIII condemned the practice of basing wages solely on the laws of supply and demand because it was mechanistic and materialistic. Free market wages did not consider the human element. Similarly, certain products and services today cannot be justified merely because the market allows for them. If the production of products is to be a human activity, it must take on a moral character. The following "ethical test" 
questions are useful: Does the product or service contribute to the real needs (and not merely the frivolous wants) of society? Is the production of the product a wise use of resources? Does the product show good stewardship by management? While these questions are not easy to answer, they should be considered because they comply with a dignified character of work.

One of the most stinging criticism Centesimus Annus has of a market driven economy is the prevalence of conspicuous consumption or what the document calls "consumerism." It explains that societies reveal their philosophy of life through their productive and consumptive choices. If the production and consumption of goods and services are absolutized to the point where they are the center of "social life and society's only value, not subject to any other value", then that particular society reveals a materialistic philosophy (CA, 39). This situation is destructive of the physical and spiritual health of people. What is produced and consumed "must be guided by a comprehensive picture of man which respects all the dimensions of his being and which subordinates his material and instinctive dimensions to his interior and spiritual ones (CA, 36). Based on this understanding of the human person, consumption and production ought to be guided by the virtues of munificence and moderation as well as the principle of the common good. Producers should not surrender responsibility of their choices to the impersonal forces of the organization or the market.

\section{Conclusion}

In the CST, work emanates from the person. It is directed toward the development of an external object, and at the same time changes the subject who performs the work. From this understanding of work we derive four essential dimensions of work (formation, remuneration, process, and product). Because of the relational nature between work's objective and subjective aspects, work is conceived by CST as a matter of virtues and principles. The knowledge of principles help to articulate and define what "good work" is. The practice of virtue helps people develop their potentialities according to their nature as well as shape society in a way that promotes a better world. Through the practice of virtues and principles in organizations, workers are perfected by directing their labor toward objects harmonious with 
what is good for human life as well as their own development. This is why a discussion of virtues and principles is so important in understanding work. Virtues such as munificence as well as solidarity, prudence, fortitude, temperance, justice, industriousness, diligence, charity, and so forth, and principles such as common use and participation, as well as human dignity, common good, preferential option for the poor, subsidiarity, etc. perfect the human person while at the same time perfect society. ${ }^{24}$ The significance of such virtues and principles, in relation to the dimensions of work, has positive practical implications which were discussed in terms of ESOPs, work-teams, and socially responsible products.

Anyone charged with the responsibility of organizing a workplace who takes the principles and virtues of CST seriously cannot ignore the concerns of what happens to the person through the process of work, the remuneration received, and the effects of the product. Some managers advocate progressive participative and remunerative programs, as well as the production of environmentally friendly products, not because they are good for the worker and society, but because they are efficient and profitable. ${ }^{25}$ What usually lurks behind such intentions is the view that the only fiduciary responsibility of management is an economic duty to owners. What is lost, however, is the personal and social responsibility that management has to employees and society as captured by the notion of work's formative dimension. Of course financial concerns are necessities in the organizational world, but they are not the only factors in running an organization. Work must concern itself not only with a person doing well but also with doing good. As CA maintains, "Profit is a regulator of the life of a business but it is not the only one; other human factors must also be considered which, in the long term, are at least equally important for the life of a business" (CA, 35).

James Renier, the president of Honeywell, expressed this point in terms of worker participation when he was asked why he had advocated participation for ten years before gaining any support from his fellow managers:

If we help people develop into the best they can become, and if we enable people to make their maximum contribution on the job, we will get the innovation and productivity we need. But I suggest to you

Journal of Business Ethics, Vol 12, No. 12 (December 1993): pg. 981-994. DOI. This article is @ Springer and permission has been granted for this version to appear in e-Publications@Marquette. Springer does not grant permission for this article to be further copied/distributed or hosted elsewhere without the express permission from Springer. 
that even if it did not get more productivity or make the company more secure, or improve profits, it would still be worth doing. It would be worth doing simply because it is the right thing to do. ...Think of it [participation] as an ethical undertaking. That will insure that programs like...quality work life help our people achieve their objectives and do not degenerate to mere manipulation. ${ }^{26}$

Similarly, the CST maintains participation as a moral principle that stems from the belief in the dignity of the worker. That is, workers are not mere extensions of capital. Their labor, their ideas, creativity, ingenuity, as well as their physical energy, have a formative influence on their personal development. Participation, like worker ownership and production of socially responsible products, will in the long run probably be the best financial strategy, but the foundation of such action should be moral rather than financial.

\section{Notes}

${ }^{1}$ For a historical survey of the subjective aspect of work see Gini, A. R. and Sullivan, T.: 1987, Work: The Process and the Person', Journal of Business Ethics 6, pp. 649-655. For a fuller explanation of the subjective and objective distinction see Naughton, Michael: 1992, The Good Stewards: Practical Applications of the Papal Social Vision of Work (University Press of America, Lanham), chap. 1.

${ }^{2}$ Some may dispute this point since it does not recognize parenthood as work, because there is no formal remunerative dimension. Anyone who is a parent knows that parenting is work. However, the work that is discussed in this article restricts work to employment from which a person earns a living. While a parent who stays home with his/her children saves money in day care, the person is not able to earn a living by staying home with his/her children. This point is in no way a slight to parenting. Much of what is discussed in this article relates to the experience of parenting, but the overall nature of work in this article is directed to formal employment.

${ }^{3}$ Bellah, Robert et al.: 1985, Habits of the Heart (Harper and Row, New York), p. 66.

${ }^{4}$ Ibid.

${ }^{5}$ Ibid.

6Mullin, Richard: 1988, 'The Work Ethic of the Bishop's Pastoral on the Economy', Journal of Business Ethics, p. 422.

${ }^{7}$ Bellah, Robert et al.: 1991, The Good Society (Alfred A. Knopf, Inc, p. 43. ${ }^{8}$ Ibid.

Journal of Business Ethics, Vol 12, No. 12 (December 1993): pg. 981-994. DOI. This article is @ Springer and permission has been granted for this version to appear in e-Publications@Marquette. Springer does not grant permission for this article to be further copied/distributed or hosted elsewhere without the express permission from Springer. 
NOT THE PUBLISHED VERSION; this is the author's final, peer-reviewed manuscript. The published version may be accessed by following the link in the citation at the bottom of the page.

${ }^{9}$ Habits of the Heart, pp. 287-288.

${ }^{10}$ Ronald Pilenzo, president of the American Society for Personnel

Administration has recently echoed this very point. He explains that for the past 75 years managers have been trained to be autocrats, but today the worker is different. "They have more education, are more self-directed or want to be, and want control their working conditions" (Bacas, Harry: 1985 (Mai), 'Who's in Charge Here?', Nation's Business, p. 57).

${ }^{11}$ Nell-Breuning, Oswald von: 1936, Reorganization of Social Economy (The Bruce Publishing Co., Milwaukee), p. 115; see Joseph Husslein's brief commentary on this passage: 1931, The Christian Manifesto (The Bruce Publishing Co., Milwaukee), p. 135. Nell-Breuning's commentary is significant since he wrote QA for Pius XI.

${ }^{12}$ Nell Breuning, p. 116. Magnificence and munificence are identical. Often, however, magnificence is translated as liberality. While the two virtues are similar they are not identical. See Aquinas Summa Theologica, IIaIIae, q. 117 and q. 134.

${ }^{13}$ For a further understanding of the virtue of munificence, see Thomas Aquinas who explains that for an act to take on the virtue of munificence (what he calls magnificence), the performance of the act must be the production of something in an external object such as building a house (IIa-IIae, q. 134, ad, 2).

${ }^{14}$ While most authors are positive about the development of ESOPs, gainsharing, work-teams, quality circles, QWL, etc., they constantly warn of their possible abuse whether intentional or not. See Drago, Robert: 1988 (Fall), 'Quality Circle Survival: An Exploratory Analysis', Industrial Relations 27, pp. 336-351; Marks, Mitchell Lee: 1987, 'The Question of Quality Circles', in Organ, Dennis W. (ed.) The Applied Psychology of Work Behavior (Business Publication Inc., Plano), pp. 340-349; Metzgar, Jack (ed.): 1989 (Fall), Participating in Management. Labor Research Review, vol. 14 (Midwest Center for Labor Research, Chicago); Rosen, Corey and Quarrey, Michael: 1987 (September/October), 'How well is employee ownership working?', Harvard Business Review 65, pp. 126-135; Hoerr, John: 1989, 'The Payoff From Teamwork', Business Week 10 July 1989, pp. 56-62 and 'ESOPs: Revolution of Ripoff?', Business Week, 15 April 1985, pp. 94107.

${ }^{15}$ Rosen, Corey and Quarrey, Michael: 1987 (September/October), 'How well is employee ownership working?', Harvard Business Review 65, pp. 126-135; see also Quarrey, Michael, Blasi, Joseph and Rosen, Corey: 1986, Trading Stock: Employee Ownership at Work (Ballinger Publishing Co., Cambridge).

${ }^{16}$ Rosen and Quarrey, p. 128.

Journal of Business Ethics, Vol 12, No. 12 (December 1993): pg. 981-994. DOI. This article is @ Springer and permission has been granted for this version to appear in e-Publications@Marquette. Springer does not grant permission for this article to be further copied/distributed or hosted elsewhere without the express permission from Springer. 
NOT THE PUBLISHED VERSION; this is the author's final, peer-reviewed manuscript. The published version may be accessed by following the link in the citation at the bottom of the page.

${ }^{17}$ Ibid.

${ }^{18}$ Ghilarducci, Teresa: 1989 (April), 'John Paul II and American workers in the Emerging Fourth World', paper presented at 'The Center of Ethics and Religious Values in Business,' (Notre Dame, IN), pp. 24-26; see Wright, Erik et al.: 1982 (December), The American Class Structure', American Sociological Review 47, p. 718

${ }^{19}$ Hoerr, John: 1989, 'The Payoff From Teamwork', Business Week, 10, July 1989, p. 58.

${ }^{20}$ Hardy, Lee: 1990, The Fabric of This World (William B. Eerdmans Publishing Company, Grand Rapids), p. 181.

${ }^{21}$ Boyett, Joseph H. and Conn, Henry P.: 1990, Workplace 2000 (A Dutton Book, New York), p. 255; see pp. 241-273 for a discussion on workteams.

${ }^{22}$ Donahue, James: 1987 (Spring/Summer), 'The Social Theology of John Paul II and His Understanding of Social Institutions', Social Thought 13, p. 25.

${ }^{23}$ Land, Philips: 1980, 'The Earth is the Lord's: Thoughts on the Economic Order', in Thomas E. Clarke (ed.), Above Every Name (Paulist Press, Ramsey), p. 227.

${ }^{24}$ Fortunately, Dennis Organ and others are attempting to explore and research the concept of 'Organizational Citizenship Behavior' (OCB). OCB is an attempt to understand the values of altruism, conscientiousness, sportsmanship, courtesy, and civic virtue that pervade the culture of organizations (Organ, Dennis W.: 1988, Organizational Citizenship Behavior (Lexington Books, Lexington).

${ }^{25}$ See Workplace 2000.

${ }^{26} \mathrm{O}$ 'Toole, James 1985, Vanguard Management: Redesigning the Corporate Future (Doubleday, New York), p. 133.

\section{References}

Bellah, Robert, N., Madsen, Richard, Sullivan, William M., Swidler, Ann and Tipton, Steven M.: 1985, Habits of the Heart (Harper and Row, New York).

Bellah, Robert, N., Madsen, Richard, Sullivan, William M., Swidler, Ann and Tipton, Steven M.: 1991, The Good Society (Alfred A. Knopf, Inc., New York).

Boyett, Joseph and Conn, Henry P.: 1990, Workplace 2000 Dutton, New York).

Donahue, James: 1987, 'The Social Theology of John Paul II and His Understanding of Social Institutions', Social Thought, Vol. 13.

Drago, Robert: 1988, 'Quality Circle Survival: An Exploratory Analysis', Industrial Relations, Vol. 27.

Journal of Business Ethics, Vol 12, No. 12 (December 1993): pg. 981-994. DOI. This article is @ Springer and permission has been granted for this version to appear in e-Publications@Marquette. Springer does not grant permission for this article to be further copied/distributed or hosted elsewhere without the express permission from Springer. 
NOT THE PUBLISHED VERSION; this is the author's final, peer-reviewed manuscript. The published version may be accessed by following the link in the citation at the bottom of the page.

Ghilarducci, Teresa: 1989 (April), 'John Paul II and American Workers in the Emerging Fourth World', Paper presented a the 'The Center of Ethics and Religious Values in Business' (Notre Dame, IN).

Gini A.R. and Sullivan, T.: 1987, 'Work: The Process and the Person' Journal of Business Ethics, Vol. 6.

Hardy, Lee: 1990, The Fabric of This World (William B. Eerdmans Publishing Company, Grand Rapids).

Hoerr, John: 1989, 'The Payoff From Teamwork', Business Week, July 10.

Hoerr, John: 1985, 'ESOPs: Revolution or Ripoff?', Business Week, April 15.

John XIII, Pope: 1961, Mater et Magirra, in Walsh, Michael and Davies, Brian (eds.), Proclaiming Justice and Peace, 1984 (Twenty-Third

Publications, Mystic).

John Paul, Pope: 1981, Laborem Exercens in Walsh, Michael and Davies, Brian (eds.), Proclaiming Justice and Peace, 1984 Twenty-Third Publications, Mystic).

John Paul, Pope: 1991, Centesimus Annus (Liberia Editrice Vaticana, Vatican City).

Land, Philip: 1980, 'The Earth is the Lord's: Thoughts on the Economic Order', in Clarke, Thomas E. (ed.) Above Every Name (Paulist Press, Ramesy).

Leo XIII, Pope: 1891, Rerum Novarum (St. Paul Editions, Boston).

Marks, Mitchell Lee: 1987, 'The Question of Quality Circles', in Organ, Dennis W. (ed.) The Applied Psychology of Work Behavior (Business Publications Inc., Plano).

Metzgar, Jack (ed.): 1989, 'Participating in Management', Labor Research Review, Vol. 14.

Mullin, Richard: 1988, 'The Work Ethic of the Bishop's Pastoral on the Economy', Journal of Business Ethics.

Naughton, Michael: 1992, The Good Stewards; Practical Applications of the Papal Social Vision of Work (University Press of America, Lanham).

Nell-Breunning, Oswald: 1936, Reorganization of Social Economy (The Bruce Publishing Company, Milwaukee).

Organ, Dennis: 1988, Organizational Citizenship Behavior (Lexington Books, Lexington).

O'Toole, James: 1985, Vanguard Management: Redesigning the Corporate Future (Doubleday, New York).

Pius XI, Pope: 1931, Quadragesimo Anno (St. Paul Editions, Boston).

Rosen, Corey and Quarrey, Michael: 1987, 'How well is employee ownership working?', Harvard Business Review, Vol. 65.

Michael Naughton is Assistant Professor of Management and Theology at the University of St. Thomas (MN). Dr. Naughton's major research interest involves examining the influence and application of religious values on employees and the workplace environment.

Journal of Business Ethics, Vol 12, No. 12 (December 1993): pg. 981-994. DOI. This article is @ Springer and permission has been granted for this version to appear in e-Publications@Marquette. Springer does not grant permission for this article to be further copied/distributed or hosted elsewhere without the express permission from Springer. 
NOT THE PUBLISHED VERSION; this is the author's final, peer-reviewed manuscript. The published version may be accessed by following the link in the citation at the bottom of the page.

Gene R. Laczniak is Professor of Business in the Department of Marketing at Marquette University. His primary research interests focus on the social influence of business activities on society as well as marketing strategy. 